\title{
DEVER DE COLABORAÇÃO DAS PARTES COM O PROCESSO: O PROCESSO CIVIL COOPERATIVO
}

\section{THE DUTY OF COOPERATION OF THE PARTIES TO THE PROCESS: THE COOPERATIVE CIVIL PROCESS}

Isadora Minotto Gomes Schwertner ${ }^{1}$

\begin{abstract}
RESUMO
A relação jurídica processual é fortemente marcada pelo debate das partes, as quais ocupam posições antagônicas no processo, cada qual na defesa dos seus interesses, em razão da necessidade de obtenção do objeto disputado em juízo. O presente artigo propõe uma nova visão do processo civil, mais compatível com a ideia do Estado Constitucional, na medida em que apregoa a necessidade de atuação das partes pautada na boa-fé e na necessidade de cooperação, não apenas com a administração da justiça, mas com a concretização dos ideais de justiça. Para tanto, as partes deverão atuar em estado de cooperação, favorecendo o diálogo e a plena realização dos atos processuais. É ainda imperioso que o Juízo conduza o processo de forma a garantir o contraditório pleno, viabilizar a pronta realização dos atos processuais, cientificar as partes acerca dos atos processuais antes de proferir qualquer decisão que interfira fundamentalmente no deslinde da causa, bem como motivar amplamente suas decisões. O problema reside em delimitar até que ponto a legislação poderá exigir este atuar cooperativo da parte no processo, já que cada qual defende interesses antagônicos. Partindo-se de uma metodologia jurídica baseada no formalismo-valorativo ou, para alguns autores, no neoconstitucionalismo, o processo civil da atualidade se explica como um meio de comunicação democrático que propõe a análise do processo partindo-se de alguns pressupostos, quais sejam, a participação das partes no processo, a crítica ao positivismo excessivo e a preocupação com a segurança jurídica, o devido processo legal e o contraditório. Um dos principais problemas que circundam o tema reside justamente em analisar o papel da parte no processo civil, delimitando até que ponto é viável, sob o ponto de vista jurídico, exigir um atuar cooperativo da parte no sentido de se obter uma solução justa no processo, ainda que desfavorável aos seus próprios interesses.

Há que se ressaltar ainda, a atuação do próprio órgão jurisdicional que deverá deixar de ser produto mecânico resultante de atos prévios puramente logísticos. Os juízes contemporâneos deverão se afastar do mero silogismo jurídico, pois incompatível com a vigilância democrática que deverão exercer no processo.
\end{abstract}

Palavras-chave: Processo civil, Cooperação, Devido processo legal

\begin{abstract}
The procedural legal relationship is strongly marked by the debate of the parties, which hold antagonistic positions in the process, each in defense of their interests, because of the need to obtain the disputed object in court. This article proposes a new vision of civil procedure, more compatible with the idea of the constitutional state, in that touts the need for action of the parties ruled in good faith and the need for cooperation not only with the administration of justice, but with the realization of the ideals of justice. To this end, the parties shall act in a state of cooperation, favoring dialogue and the fulfillment of procedural acts. It is also

\footnotetext{
${ }^{1}$ Doutorada em Direito do Estado e das Relações Sociais pela Universidade Federal do Paraná, Paraná, (Brasil). Professora pela Universidade Estadual do Oeste do Paraná, Paraná, (Brasil). E-mail: isadoragomes@ hotmail.com
} 
imperative that the judgment will lead the process to ensure the full contradictory, facilitate the expeditious holding of procedural acts, to notify the parties about procedural acts before issuing any decision that fundamentally interfere in disentangling cause and motivate their widely decisions. The problem lies in defining the extent to which legislation may require this cooperative work part in the process, as each defends antagonistic interests. Starting from a legal methodology based on formalism-evaluative or, for some authors, the neoconstitutionalism, the current civil process is explained as a means of democratic communication proposing the analysis of the process starting with some assumptions, namely, the participation of the parties, criticism of excessive positivism and the concern for legal certainty, due process and the contradictory. One of the main issues surrounding the subject is that he examine the role of the party in civil proceedings, limiting how far it is feasible, from a legal point of view, require a cooperative act the part in order to obtain a just solution in the process even if unfavorable to their own interests. It must be emphasized also the role of the court itself that should be converted from mechanical product resulting from purely logistical previous acts. Contemporary Judges should move away from mere legal syllogism as incompatible with democratic supervision they are to perform in the process.

Keywords: Civil process, Cooperation, Due process 


\section{INTRODUÇÃO}

O presente estudo tem por fundamento analisar a atuação das partes no processo, com vistas à concretização dos valores democráticos no plano das relações jurídicas processuais, as quais tradicionalmente são vistas como local de debate e antagonismo. O processo civil cooperativo tem por objetivo a análise da relação processualística como meio de diálogo entre as partes, visando uma atuação pautada na boa-fé, ética, colaboração e lealdade.

O trabalho objetiva analisar brevemente o direito processual civil sob o prima do formalismo-valorativo, o qual propõe a condução da relação jurídica processual como fenômeno cultural, interpretando e sistematizando as bases metodológicas em conformidade com os princípios preconizados pelo Estado Constitucional contemporâneo e forma através da qual o processo deverá ser conduzido tendo como norte a organização política adotada pela sociedade, voltada sempre para a concretização dos direitos fundamentais no plano das relações jurídicas de direito material e no plano processual.

Como mecanismo de concretizar o dever de colaboração das partes no processo será analisado também os métodos dos quais dispõe o legislador na tentativa de incutir nos sujeitos processuais a atuação ética, proba e leal, como forma de melhor adequar a interpretação legislativa processual, tradicionalmente pragmática e operativa, em consonância com a filosofia comunicativa e participativa democrática, no intuito de se alcançar a legimitidade e representatividade pretendidas. Trata-se da participação democráticojurisdicional das partes no processo, preconizada pelo método interpretativo neoconstitucionalista e democrático, voltada para a concretização da prestação jurisdicional de forma justa e efetiva.

Primeiramente, destaca-se a importância do tema pela necessidade de se construir o Direito, mais especificamente o direito processual civil, como instrumento democrático. Para alcançar este desiderato, o direito deverá ser estudado como fenômeno social, na sua dimensão hermenêutica, reconhecendo-lhe a condição de ciência da compreensão para posteriormente investigar a legitimação da criação jurisprudencial. ${ }^{2}$

\footnotetext{
${ }^{2}$ SILVA. Ovídio Baptista. Processo e Ideologia: O Paradigma Racionalista. Rio de Janeiro: 2006, p. 37.
} 
Entretanto, apenas a cooperação espontânea das partes ou do juízo não basta para que o processo alcance seu desiderato. É necessária a existência de legislação, que garanta às partes que os direitos fundamentais sejam exercidos no plano da relação jurídica processual, tal como apregoa Robert Alexy. ${ }^{3}$

Ainda, analisando a atuação da parte no processo, na consecução dos interesses próprios, não poderá obstaculizar a concretização nem a administração da justiça. A questão que surge é a necessidade de abandonar parcialmente a visão liberal, individualista da parte no sentido de defender apenas e tão somente seus próprios interesses, em detrimento da boa administração da justiça, exigindo atos de cooperação com o resultado do processo. Outro ponto relevante da pesquisa consiste em analisar os meios dos quais dispõe o legislador no intuito de exigir da parte a atuação pautada na ética e boa-fé, verificando os dispositivos existentes no ordenamento jurídico brasileiro, no projeto do Código de Processo Civil e no direito comparado, com o intuito de exigir a participação cooperativa.

A definição mínima de democracia, conforme proposta por Norberto Bobbio apregoa que um regime democrático se constrói primariamente por meio de um conjunto de regras de procedimento que permite a formação de decisões coletivas, em que são previstas regras que facilitem a participação mais ampla possível dos interessados. ${ }^{4}$

No projeto do Código de Processo Civil existem várias passagens que acentuam a ideia do processo civil cooperativo. Contém o referido projeto várias normas que densificam o dever de colaboração do Estado para com o jurisdicionado e muitas situações estão previstas em que o jurisdicionado deverá colaborar com a regularidade da relação jurídica processual.

\section{A ATUAÇÃO DAS PARTES E DO JUÍZO NO PROCESSO CIVIL CONTEMPORÂNEO}

Luiz Guilherme Marinoni ressalta positivamente a previsão dos deveres de esclarecimento, prevenção, diálogo e auxílio inerentes à colaboração ao longo de todo o Projeto do Código de Processo Civil, embora o Projeto não o tenha contemplado de forma expressa. ${ }^{5}$ 
O dever de colaboração das partes no processo deverá ser acolhido como princípio fundamental do processo, pois necessário à administração da própria justiça, para se obter um processo mais justo e igualitário, tornando o dever de colaboração como decorrência do direito fundamental à participação no processo, conforme dispõe o artigo $5^{\circ}$, LV da Constituição Federal.

O Artigo $5^{\circ}$ do Projeto do Código de Processo Civil dispõe: “As partes têm o direito de participar ativamente do processo, cooperando entre si e com o juiz e fornecendo-lhe subsídios para que profira decisões, realize atos executivos ou determine a prática de medidas de urgência".

Por certo que o dever de colaboração das partes deverá ser direcionado ao Poder Judiciário, à administração da justiça, em razão de as partes ocuparem posições antagônicas no processo contencioso, o que afastaria uma interpretação literal do dispositivo supracitado do anteprojeto. De fato, ao colaborar com os atos processuais e com o regular andamento do feito, inevitável e indiretamente, estaria uma das partes colaborando com a parte contrária. Entretanto, a leitura que deverá ser feita do dispositivo em comento é a de que a colaboração imposta é aquela que deve ocorrer entre o juízo e as partes e das partes com o Juízo.

Para se alcançar um processo colaborativo e, por consequência, justo, é necessário desenvolver a paridade de tratamento e um efetivo contraditório, ambos assegurados nos artigos $5^{\circ}$, incisos I e LV da Constituição Federal. Um processo democrático não poderá ocorrer sem que as partes se encontrem em igualdade de condições para dialogar e, cada qual, buscar a concretização dos seus interesses no plano processual.

Isso porque o texto constitucional já não pode mais ser entendido como um mero marco normativo regulamentador das relações do Estado com os cidadãos em condições de pluralismo social e cultural, tampouco como uma ordem jurídica global que imponha a priori à sociedade uma determinada forma de vida.

\footnotetext{
${ }^{3}$ ALEXY, Robert. La Construcción de Los Derechos Fundamentales. Buenos Aires: Ad-hoc, 2010, p. 81. ${ }^{4}$ BOBBIO, Norberto. O Futuro da Democracia: Uma defesa das regras do jogo. Rio de Janeiro: Paz e Terra. 1997 , p. 12.

${ }^{5}$ MARINONI, Luiz Guilherme; MITIDIERO, Daniel. O Projeto do CPC: Críticas e Propostas. São Paulo: Ed. RT, 2010, p. 73.
} 
A Constituição, antes de qualquer coisa, fixa os procedimentos políticos conforme os quais os cidadãos, exercitando seu direito de autodeterminação, podem perseguir cooperativamente e com perspectiva de êxito o projeto de estabelecer concretamente os direitos e garantias assegurados na própria Constituição, como forma legitimadora de toda a atuação legislativa.

A democracia, da mesma forma que o direito, se caracteriza pela construção, progresso e desenvolvimento das suas ideologias básicas, em um cenário de conflito, tendo-o como uma das suas virtudes naturais. Como afirma Ovídio Baptista da Silva:

(...) uma vez transposto o paradigma dogmático, encontraremos terreno propício para que o processo desenvolva-se em harmonia com uma sociedade complexa e pluralista, cuja marca fundamental é o individualismo das grandes multidões urbanas. ${ }^{6}$

A atividade interpretativa do juiz não deve se prender a um sistema hermenêutico fechado e único, ao revés, deve levar em consideração o contexto histórico, social e interdisciplinar, como instrumento da democracia, tal qual propõe Elio Fazzalari:

Sociologia, storia, giurisprudenza, alle quale si accompagna la comparazione nei soi vari livelli, sono infatti, scienze diverse, le quali però cospirano in uno sforzo interdiciplinare; si collocano cioè in um rapporto che costituisce il più maturo prodotto della vocazione verso l'unità delle scienze, e per Il qualse Il possesso dei risultati di ciascuna è indispensabile per la elaborazione delle altre. $^{7}$

A jurisdição deverá ser preservada de modo a assegurar o papel de instrumento democrático. Neste sentido a técnica processual poderia contribuir para a formação de um cenário condizente com o exercício da democracia.

Segundo Jürgen Habermas:

(...) o modo de operar de um sistema político, constituído pelo Estado de direito, não pode ser descrito adequadamente, nem mesmo em nível empírico, quando não se leva em conta a dimensão de validade do direito e a força legitimadora da gênese democrática do direito. ${ }^{8}$

O que propõe o presente estudo é uma visão mais democrática do processo civil, analisando a relação jurídica processual como instrumento da democracia, com a possibilidade de ampla participação das partes na formação dos resultados do processo.

Esta tendência democratizante já encontra previsão no projeto do Código de Processo Civil, que prevê no artigo 10 e 110, parágrafo único que, antes de decidir a 
respeito de qualquer matéria, inclusive aquelas sobre as quais poderia o juízo decidir de ofício, deverá o magistrado possibilitar a manifestação prévia das partes.

Ao repensar a relação jurídica processual, surgem para o Juízo basicamente três deveres, quais sejam: dever de consulta, dever de esclarecimento e de prevenção ou proteção. Diante do dever de consulta, devem-se consultar as partes sobre pontos relevantes do processo, ainda que possam ser conhecidos sem provocação das partes.

Quanto ao dever de esclarecimento, os atos realizados pelo juiz e seus auxiliares, bem como os atos praticados pelas partes deverão ser o mais claro e inteligível possível, evitando- se situações que possibilitem interpretações dúbias ou obscuras. ${ }^{9}$

O dever de prevenção ou proteção implica na atuação diligente e atenta do Juízo quando à ocorrência dos vícios processuais, os quais deverão sempre ser apontados e corrigidos, evitando nulidades e refazimento de atos, o que importaria em inobservância dos princípios da economia, celeridade processual e razoável duração do processo.

É necessária a promoção de um diálogo entre as partes e entre estas e o Magistrado, a fim de que seja possibilitada a formação de um contraditório pleno entre as partes e o Poder Judiciário. Devem-se evitar tanto quanto possível as decisões-surpresa, as quais são constantemente proferidas no curso do processo, da forma como conduzido atualmente. No processo civil cooperativo, o Magistrado deve abandonar a ideia do mero fiscal de regras, devendo adotar uma posição de agente colaborador, de participante ativo, com a função precípua de redimensionar o diálogo processual.

A cooperação das partes e do juízo no processo pode ser tida como expressão da democracia, no seu aspecto participativo, na medida em que promove o diálogo e discussão, tendo como cenário o âmbito jurisdicional.

\footnotetext{
${ }^{6}$ SILVA. Ovídio Baptista. Processo e Ideologia: O Paradigma Racionalista. Rio de Janeiro: 2006, p. 48.

${ }^{7}$ FAZZALARI, Elio. L'esperienza del processo nella cultura contemporânea. Rivista di diritto processuale, 1965, p.20.

${ }^{8}$ HARBERMAS, Jürgen. Direito e Democracia: entre facticidade e validade. Vol II. Rio de Janeiro: Tempo Brasileiro, 1997, pg. 9.

${ }^{9}$ MIRAndA, Pontes de. Prólogo. Comentários ao Código de Processo Civil. 2a . Ed. Rio de Janeiro: Forense, 1958.
} 
Cidadãos livres e em igualdade de participação demonstram melhores condições de debater as teses apresentadas legitimando as decisões judiciais, em razão do contexto criado, pautado pelos princípios da inclusão, do pluralismo, da igualdade participativa, da autonomia e da justiça social, democratizando a relação jurídica processual.

\section{PROCESSO CIVIL E ESTADO CONSTITUCIONAL}

A atividade jurisdicional orienta-se por duas grandes classes principiológicas. A primeira refere-se aos princípios estritamente processuais, relacionados ao sistema a que se filiam, cuja finalidade é a de concatenar as regras do ordenamento estatal com as necessidades sociais e políticas do Estado.

A segunda classe constitui-se pelos princípios constitucionais processuais, cuja função é preordenar a elaboração de leis infraconstitucionais e reger as relações entre governantes e governados. Inevitavelmente os princípios constitucionais repercutem no campo do processo civil, já que exprimem direitos públicos invocáveis em Juízo, os quais se aplicam tanto à Organização Judiciária quanto ao exercício da Jurisdição.

Paulo Roberto de Gouvêa Medina, analisando as classes principiológicas acima expostas, leciona:

“(...) Os princípios constitucionais do processo, em razão mesmo de sua natureza, têm caráter cogente, não indicando meras opções de políticas legislativas que o elaborador da lei processual possa adotar, ou não, segundo o modelo preferido. Já os princípios estritamente processuais, constituindo as 'diretivas ou linhas mestras, dentro das quais hão de desenrolar-se as instituições do processo', são perfilhados pelo legislador quando lhe pareça conveniente adotá-los. (...)"10

Ambas as categorias de princípios interferem de modo bastante importante na hermenêutica processual, vez que as normas processuais, a exemplo do que ocorre com as demais leis infraconstitucionais, devem ser elaboradas e interpretadas conforme a Constituição Federal.

\footnotetext{
${ }^{10}$ MEDINA. Paulo Roberto de Gouvêa. Direito Processual Constitucional. Rio de Janeiro: Forense, 2010, pg. 34.
} 
Os princípios constitucionais aplicáveis às relações jurídicas constitucionais constituem-se na pura expressão do Estado Democrático de Direito, e, possuem como diretriz de interpretação a dignidade do ser humano. Logo:

“(...) Como consectário óbvio, toda atuação pautada pela instrumentalidade deve ter como parâmetro mínimo a preservação dos princípios constitucionais do processo e como finalidade a concretização do Estado Democrático de Direito. (...)"11

Inexiste atuação democrática onde a relação jurídica processual se desenvolve em desrespeito aos princípios constitucionais, sem buscar a implementação dos ideais do Estado Democrático de Direito.

Ao propor a Teoria do Discurso, Robert Alexy apregoa que a relação entre a teoria do discurso e o Estado Constitucional Democrático desenvolvem-se em três passos, como se vê:

(...) En el primero se aborda la necesidad del derecho y del Estado. Esto constituye la fundamentación del Estado formal de derecho. En el segundo paso se expone la necesidad de la democracia. Conjuntamente, ambos pasos integran la fundamentación del Estado democrático de derecho. Sobre esta base se eleva el tercer peldano, que conduce a la necesidad de sujetar el proceso democrático a vinculaciones de contenido y aseguralas institucionalmente. De ahí resulta el Estado constitucional democrático. ${ }^{12}$

Marcus Orione Gonçalves Correia, ao discorrer sobre a o processo constitucional, destaca a atuação jurisdicional:

(...) nessa ideia de participação do juiz no processo, retirando-se da postura passiva e buscando o equilíbrio real entre as partes, há que se constatar a importância das conclusões anteriores. Em algumas situações, o limite entre a atuação tendente à maximização dos ideais democráticos e aquela que acaba por tender à arbitrariedade é muito tênue, somente podendo ser transposto se observados os princípios processuais constitucionais e se a participação, por si só, for tendente à efetivação da dignidade do homem. No entanto, a ausência de atuação, quando se deveria buscar o verdadeiro equilíbrio entre as partes naturalmente desiguais, pode redundar em negação da Democracia e da própria busca da efetivação, pelo processo, desta mesma dignidade. $(\ldots)^{13}$

Daí a necessidade de interpretar o direito processual com base nos preceitos constitucionais, transformando a Constituição em elo metodológico indispensável para compreender o processo civil e sua técnica na atualidade. 
No que se refere ao direito de acesso ao Poder Judiciário, expressão do princípio da inafastabilidade previsto textualmente no corpo constitucional no art. $5^{\circ}$, inciso $\mathrm{XXXV}$, o direito de ação e o direito ao processo representam os mecanismos previstos para solicitação da atuação jurisdicional, em respeito ao princípio da inércia.

O conceito de ação tem ocasionado diversos posicionamentos doutrinários. Sem adentrar de forma aprofundada no tema, o direito de ação poderá ser resumido no direito que se confina na provocação do exercício da função jurisdicional. Liebman, à semelhança do que apregoa Chiovenda, conceitua a ação como sendo o poder de realizar a condição que põe em exercício o órgão judicante para fazer valer a vontade da lei por meio da sua aplicação ao caso concreto.

Trata-se do direito de provocar a prestação jurisdicional a um pronunciamento acerca do seu conteúdo, do seu objeto. Representa o direito de pedir ao Estado a prestação de sua atividade jurisdicional num dado caso concreto, por meio de uma atuação pautada na consecução dos seus fins, qual seja, a pacificação social e a proteção dos direitos ameaçados ou lesionados indevidamente. Cássio Scarpinella Bueno aduz que:

“(...) se a jurisdição é inerte e a atuação jurisdicional com vistas à prestação da tutela jurisdicional depende do rompimento desta inércia, não há como perder de vista no que consiste este 'provocar' do Estado-juiz para aqueles fins.(...)"14

Convém esclarecer que não há dois direitos de ação, uma constitucional e outro processual. O direito de ação é sempre processual, pois é por meio do processo que ele se exerce.

O que existe é a garantia constitucional genérica do direito de ação, a fim de que a lei não obstrua o caminho ao Judiciário na consecução das suas finalidades (tutelar direitos), mas o seu exercício poderá ser sempre considerado processual, correlato a um pretensão esposada em Juízo. ${ }^{15}$

\footnotetext{
${ }^{11}$ CORREIA. Marcos Orione Gonçalves. Direito Processual Constitucional. São Paulo: Saraiva, 2007, pg. 19.

${ }^{12}$ ALEXY, Robert. La Construcción de Los Derechos Fundamentales. Buenos Aires: Ad-hoc, 2010, p. 80.

${ }^{13}$ CORREIA. Marcos Orione Gonçalves. Direito Processual Constitucional. São Paulo: Saraiva, 2007, pg. 20.

${ }^{14}$ BUENO, Cássio Scarpinella. Curso Sistematizado de Direito Processual Civil, vol. 1. São Paulo: Saraiva, 2011, pg. 381.
} 
O Acesso à Justiça propõe uma reflexão e consequente sistematização do direito processual civil com vistas ao exercício da função jurisdicional para que sejam protegidos, por imposição constitucional de forma adequada, célere e eficaz, situações de ameaça ou lesão a direito. Tem-se, portanto, duas formas de atuação da tutela jurisdicional: a tutela preventiva e a tutela repressiva.

Este socorro à tutela jurisdicional poderá ocorrer de forma coletiva, pois não se pode pensar no processo apenas como mecanismo de busca da proteção ou efetivação dos direitos apenas no plano privatístico ou individualizado, dando azo a um direito processual coletivo, de caráter público, voltado para a proteção dos direitos das massas ou coletividades, na defesa dos direitos coletivos e difusos.

Toda a legislação infraconstitucional que pretenda subtrair do Poder Judiciário qualquer ameaça ou lesão a direito, não há como negar a sua inconstitucionalidade, pois o exercício do direito de ação consagrado no dispositivo constitucional supracitado (art. $5^{\circ}, \mathrm{XXXV)}$ impõe a manifestação da atuação estatal de forma adequada com vistas a concessão da tutela jurisdicional da forma como requerida. A interpretação do princípio da inafastabilidade não poderá ser restritiva, na medida em que representa um direito fundamental do ser humano, qual seja, valer-se da proteção estatal quando seus direitos são ameaçados de lesão ou lesionados, com a possibilidade de buscar a devida reparação.

Inobstante exista esta preocupação com o acesso ao Poder Judiciário, este desenrolar de atos processuais deverá seguir uma sistemática pré-determinada para que seja garantida às partes uma atuação paritária, com a possibilidade do exercício da ampla defesa pelo demandado. Trata-se do princípio do devido processo legal.

A Constituição Norte Americana adotou de forma expressa o princípio do devido processo legal, por meio de Emenda $\mathrm{n}^{\circ} 5$ de 1971, ao prever que "ninguém será privado da vida, da liberdade ou da propriedade sem o devido processo legal." Tal princípio, inicialmente de natureza tipicamente processual, representava uma garantia no controle da razoabilidade das leis e dos atos administrativos, posteriormente, razão de sua repercussão na esfera administrativa e constitucional, foi denominado de substantive due process.

${ }^{15}$ FILHO. Vicente Greco. Direito Processual Civil Brasileiro. Vol. 1. São Paulo: Saraiva, 2008, pg. 80. 
Eduardo Couture traçou algumas linhas diretivas e informadoras provenientes do contexto ideológico trazido pelo princípio do devido processo legal, destacando a ciência inequívoca do demandado acerca da ação em face dele proposta, seja de forma direta ou indireta; a oportunidade de comparecer em juízo e expor suas razões por meio da realização dos instrumentos probatórios; que o Tribunal perante o qual se processa a demanda seja regularmente constituído e imparcial; e, por fim, que este mesmo Tribunal seja competente. $^{16}$

O contingente histórico, cujo conteúdo demonstra-se relativo na medida em que varia de acordo com a evolução histórica da consciência jurídica e política de um país, também influencia na conceituação do due processo of law. Entretanto, os pilares basilares da relação jurídica processual que caracterizam o Estado Democrático de Direito, em detrimento de um Estado autoritário, permanecem praticamente inalterados.

$\mathrm{Na}$ Constituição brasileira o princípio do devido processo legal vem expresso no art. 5, LIV. Destes princípios, decorrem outros que são igualmente importantes para a compreensão da atividade jurisdicional segundo os preceitos constitucionais. Para Calmon de Passos, o devido processo legal ocorre quando presentes três condições essenciais, ou seja, só há o exercício da jurisdição constitucional quando o processo se desenvolve perante um juízo imparcial e independente, garantindo-se o acesso ao Poder Judiciário por meio de uma relação processual em que é assegurada às partes o contraditório e ampla defesa. ${ }^{17}$

O princípio do contraditório está disposto no art. $5^{\circ}, \mathrm{LV}$ da $\mathrm{CF}$, assegurando-se aos acusados em geral o direito de se contrapor aos atos e fatos que lhe são imputados nos processos judiciais e administrativos, possibilitando a prática de todos os atos de defesa e recursos previstos na legislação.

O núcleo central do princípio do contraditório pode ser resumido pelo binômio ciência e resistência ou informação e reação, sendo o primeiro termo sempre indispensável e o segundo, possibilitado.

\footnotetext{
${ }^{16}$ COUTURE. Eduardo. Fundamentos del Derecho Procesual Civil. Buenos Aires: Ediciones Depalma. 1972, pg. 150 .

17 PASSOS. Calmon. O Devido Processo Legal e o Duplo Grau de Jurisdição. São Paulo: Saraiva, 1981, pg. 86.
} 
Deverá ser sempre admitida a participação ampla da parte requerida no processo, com a possibilidade de apresentação de defesa, produção de provas, recursos, impugnar documentos e argumentos novos trazidos pela parte autora, possibilidade de revisão dos atos judiciais com conteúdo decisório, bem como praticar todos os atos processuais de resistência à pretensão que lhe é apresentada. Cássio Scarpinella Bueno afirma:

(...) o tema, que guarda inegável entrelaçamento com o princípio do contraditório na forma exposta pelo número anterior, quer evidenciar, apenas e tão somente, que, em um modelo de Estado como o brasileiro, não é suficiente a previsão formal de uma garantia processual. É mister a criação de condições mínimas e suficientes para seu escorreito exercício. Assim, não basta se defender mas também se faz necessário criar condições de se exercer adequadamente esta defesa. ${ }^{18}$

Não basta assegurar a igualdade de possibilidade às partes, mas garantir oportunidade de participar da prática de todos os atos processuais relevantes e de influir no sentido de uma decisão favorável ao seu interesse. ${ }^{19}$

Outra decorrência do princípio do devido processo legal, é o princípio do juiz natural, competente e imparcial. A autoridade judiciária que julgará o caso deverá preexistir ao fato a ser julgado. É vedada a criação de Tribunais ad hoc para decidir questões já ocorridas e especialmente para este fim, garantindo-se a imparcialidade do julgador.

Doutrinariamente, foi acentuada a importância do princípio do juiz natural com a sua elevação à categoria dos pressupostos processuais - trata-se de um pressuposto processual de existência, sem o qual é impensável a instauração da relação jurídica processual, ao lado, da competência do juízo, destaca igualmente pela doutrina processualista, como pressuposto processual de validade de prosseguimento da relação jurídica processual.

O juiz deverá ser constitucionalmente competente. No entender de Cássio Scarpinella Bueno, será juiz natural aquele que a Constituição indicar como competente, ou, quando permitir que o seja. $^{20}$

O referido princípio encontra previsão no art. $5^{\circ}$, XXXVII e LIII da Constituição Federal. José Afonso da Silva, ao tratar dos chamados Tribunais de Exceção, aduz que se trata daqueles tribunais que não integram o sistema judiciário preestabelecido, aquele criado 
apenas para o caso, ou seja, depois da ocorrência do fato objeto do processo e do julgamento, onde a Constituição Federal deverá previamente instituir para o exercício da função jurisdicional. ${ }^{21}$ Juiz imparcial é aquele apto a analisar a causa que não se encontra naquelas situações legais de suspeição ou impedimento, pois uma vez constatada sua parcialidade, o julgamento a ser proferido não será justo.

O julgador deverá analisar os argumentos trazidos pela parte e proferir um julgamento no exercício da sua independência funcional. José Frederico Marques esclarece, ao cuidar da capacidade do juiz como sujeito imparcial da relação processual, a necessidade uma "capacidade especial relativa ao exercício hic et nunc do poder jurisdicional", capacidade esta que se desdobra subjetiva e objetivamente: sob o ponto de vista objetivo, vem regulada pelas normas que disciplinam a competência; subjetivamente relaciona-se com a garantia de imparcialidade que deve oferecer todo aquele que exerça função jurisdicional. $^{22}$

Cândido Rangel Dinamarco afirma que "a manutenção do clima de segurança exige também o respeito à legalidade no trato do "processo' pelo juiz. (...)" ${ }^{23}$ Por isso é que, se de um lado no Estado moderno não mais se tolera o juiz passivo e espectador, de outro sua participação ativa encontra limites ditados pelo mesmo sistema de legalidade.

Todo empenho que se espera do juiz no curso do processo e para sua instrução precisa ser conduzido com a consciência dos objetivos e menos apego às formas como tais ou à letra da lei. Entretanto, deverá demonstrar a preocupação com a integridade do dues process of law, que representa a segurança aos litigantes. Norberto Bobbio, ao tratar das regras do jogo democrático, leciona que:

\footnotetext{
18 BUENO, Cássio Scarpinella. Curso Sistematizado de Direito Processual Civil, vol. 1. São Paulo: Saraiva, 2011, pg. 150-151.

19 MEDINA. Paulo Roberto de Gouvêa. Direito Processual Constitucional. Rio de Janeiro: Forense, 2010, pg. 42.

${ }^{20}$ BUENO, Cássio Scarpinella. Curso Sistematizado de Direito Processual Civil, vol. 1. São Paulo: Saraiva, 2011, pg. 152.

${ }^{21}$ SILVA. José Afonso. Comentário Contextual à Constituição. São Paulo: Malheiros. 2005, pg. 137.

${ }^{22}$ MARQUES. José Frederico. Instituições de direito processual civil, vol. II. Rio de Janeiro: Forense, pg. 120 a 123.
} 
“(...) a única maneira de conduzir uma discussão razoável sobre a democracia, entendida como uma forma de governo distinta de todas as outras autocráticas, consiste em considerá-la como algo que se caracteriza através de uma série de regras... que estabelecem quem está autorizado a tomar decisões envolvendo a coletividade e que tipo de procedimentos devem ser aplicados." 24

A economia processual e celeridade igualmente apresentam-se como princípios da relação jurídica processual. Representa a condução dos atos processuais no menor tempo possível e com o menor dispêndio financeiro. Trata-se de otimizar a relação jurídica processual, pois torná-la célere é torná-la, em última análise, eficaz.

Por fim, ressalta-se a razoável duração do processo, que com a Emenda Constitucional 45 de 2004 foi alçada à categoria de direitos fundamentais. O devido processo legalmente previsto deverá transcorrer em prazo hábil, pois a tramitação em tempo excessivo dificulta a defesa e a produção da prova, além de protelar a entrega da tutela jurisdicional prejudicando ou até mesmo inviabilizando, no plano empírico, o direito pleiteado pela parte. Ademais, a morosidade dilata o prazo de incertezas que a pendência de uma ação judicial provoca, com efeitos patrimoniais e até psicológicos nos jurisdicionados.

Samuel Miranda Arruda leciona:

(...) é imprescindível que ao acusado seja assegurada ampla defesa, como o tempo necessário à sua preparação. É essencial que exista aqui um sopesamento, expresso através do termo razoável. Este tempo razoável deve ser compreendido como o suficiente a possibilitar um justo julgamento, mas não tão excessivo que dilate de forma desnecessária a tramitação processual. $^{25}$

A celeridade pode ser considerada corolário da efetividade da tutela jurisdicional, sob o aspecto da necessidade de uma atuação positiva do Estado, revestindo-se de um caráter social prestacional, compondo verdadeiramente um direito fundamental.

Compete, pois ao Estado organizar um sistema jurisdicional com normas processuais claras e previamente definidas em lei que garantam um processo ágil e célere, capaz de possibilitar o acesso ao Poder Judiciário, no intuito de concretização dos direitos reclamados, como forma e obtenção da justiça.

É preciso adequar a relação jurídica processual para que sua dimensão temporal não venha a inviabilizar direitos previstos no plano material. $\mathrm{O}$ direito à tutela jurisdicional e a 
garantia do processo devido constituem referências constitucionais autônomas de onde se pode extrair a constitucionalização de um direito ao tempo no processo, para que não ocorra um comprometimento da eficácia da tutela jurisdicional ocasionada, inevitavelmente, pelos efeitos negativos do tempo aferido processualmente nas relações de direito material.

\section{COOPERAÇÃO NO PROCESSO CIVIL}

As constituições modernas, ao instituírem direitos fundamentais propagam a supercomplexidade $^{26}$ da sociedade e assimilam o pluralismo jurídico. Exercem um papel relevante na modificação da realidade, na medida em que propõem normas de caráter superior, as quais são vinculativas dos poderes públicos, com intuito de realizar os direitos fundamentais e preservar a estrutura estatal.

Para o neoconstitucionalismo a constituição é analisada como o conjunto de normas que consagram os principais valores sociais dentro do ordenamento jurídico, os quais devem ser observados com primazia na aplicação do direito, voltados para a realização do Estado Democrático de Direito.

Surge a partir daí a tutela constitucional do processo, preocupada com a concretização dos direitos fundamentais no plano processual e a jurisdição constitucional, com a previsão de mecanismos processuais que viabilizem os direitos fundamentais, bem como a proteção do texto constitucional. Tal qual preceitua Eduardo Cambi:

"O neoconstitucionalismo se propõe a superar o paradigma da validade meramente formal do direito, no qual bastava ao Estado cumprir o processo legislativo para que a lei viesse a ser expressão jurídica. [...]"27

\footnotetext{
${ }^{23}$ DINAMARCO. Cândico Rangel. A instrumentalidade do processo. São Paulo: Revista dos Tribunais. 2003. ${ }^{24}$ BOBBIO, Norberto. O Futuro da Democracia: Uma defesa das regras do jogo. Rio de Janeiro: Paz e Terra. 1997, p. 19.

25 ARRUDA. Samuel Miranda. O Direito Fundamental à Razoável Duração do Processo. Brasília: Editora Brasília Jurídica. 2006, pg. 93.
} 
Surge a partir daí a tutela constitucional do processo, preocupada com a concretização dos direitos fundamentais no plano processual e a jurisdição constitucional, com a previsão de mecanismos processuais que viabilizem os direitos fundamentais, bem como a proteção do texto constitucional. Tal qual preceitua Eduardo Cambi:

"O neoconstitucionalismo se propõe a superar o paradigma da validade meramente formal do direito, no qual bastava ao Estado cumprir o processo legislativo para que a lei viesse a ser expressão jurídica. [...]”27

O neoprocessualismo procura constituir técnicas processuais voltadas à promoção do direito fundamental à adequada, efetiva e célere tutela jurisdicional, rompendo com o formalismo dos métodos processuais. O processo deve ser pensado sob o enfoque da cidadania ativa e solidária. ${ }^{28} \mathrm{O}$ processo conduzido sob o aspecto puramente formal torna-se um processo pobre e engessado em que não se atende aos anseios das partes, nem promove de forma plena a tutela jurisdicional.

O processo democrático compreende a participação dos sujeitos do processo de forma cooperativa, guardando ao juiz o dever de fundamentação das decisões e às partes o dever de debates e direito de convencimento ${ }^{29}$, tal qual:

Ao conduzir o diálogo processual, tendo como escopo final à promoção dos direitos fundamentais e à justiça da decisão, impõe-se ao juiz os deveres de esclarecimento, prevenção, consulta e auxílio dos litigantes. ${ }^{30}$

O formalismo-valorativo, ou para alguns autores, o neoprocessualismo, propõe que as decisões judiciais, no contexto do Estado Democrático Constitucional, devem ser baseadas na visão cooperativa entre os sujeitos do processo a fim de que se respeitem os direitos fundamentais, assim como tornar possível alcançar a pacificação social e uma decisão mais acertada, adequada à realidade das partes.

\footnotetext{
${ }^{26}$ CAMBI, Eduardo. Neoconstitucionalismo e Neoprocessualismo. Editora RT, 2009, p. 25.

${ }^{27}$ CAMBI, Eduardo. Neoconstitucionalismo e Neoprocessualismo. Editora RT, 2009, p. 115.

${ }^{28}$ MITIDIERO. Daniel. Colaboração no processo civil. Pressupostos sociais, lógicos e éticos. São Paulo: RT, 2009 , p. 72.

${ }^{29}$ ALVARO DE OLIVEIRA, Carlos Alberto. Poderes do Juiz e visão cooperativa do Processo. Disponível em: <http://www.mundojuridico.adv.br>. Acesso em: 20 de outubro de 2011.

${ }^{30}$ CAMBI, Eduardo. Neoconstitucionalismo e Neoprocessualismo. Editora RT, 2009, p. 116.
} 
Segundo o formalismo-valorativo, a ideia de processo cooperativo só pode ser concretizado num horizonte neoconstitucionalista e pós-positivista, promovido pela interpretação das normas, regras e princípios em conformidade com a Constituição Federal, marcado por um contraditório forte, onde seja garantido às partes o direito de influência e de debater os pontos do processo sobre os quais divergem as partes. Ao magistrado cabe o dever de não surpreender as partes com decisões terminativas ou definitivas sem antes assegurar a manifestação; de fundamentação das decisões judiciais, bem como a busca pela justiça material.

O objetivo a ser buscado com a visão cooperativa do processo é a proteção contra erros ou arbitrariedades, à medida que se tem uma atividade intelectual que ultrapassa a ação mecânica da subsunção do fato à norma, extrapola os limites do mero positivismo e amplia o alcance e aplicabilidade dos princípios da instrumentalidade das formas e da fungibilidade dos atos processuais, desenvolvendo-se um posicionamento mais consentâneo com os anseios sociais e de verdadeiro mecanismo de concretização dos direitos, no plano material.

Esta importante tarefa legitimadora é atribuída ao formalismo-valorativo, já que sua metodologia científico-jurídica é, sem violar o direito positivado, trazer o imperativo participativo para o campo processual, no intuito de construir uma legislação e um processo democráticos e que respondam às demandas da contemporaneidade.

A compreensão legitimadora orientada por um processo civil participativo compatível com o fundamento racional habermasiano ${ }^{31}$, demonstra inúmeras contribuições no campo operativo, a exemplo da possibilidade de participação no processo de figuras não tradicionais, tais como o amicus curiae no processo civil brasileiro.

Um processo civil democrático deve ser compreendido a partir da restrição de violação do direito legítimo positivado com a garantia de participação efetiva dos sujeitos do processo (partes e juiz), e outras pessoas igualmente legitimadas, o que conduz a uma maior qualidade, transparência e legitimidade do direito.

A atuação do magistrado no Estado Democrático Constitucional de adequar, em razão da necessária cooperação, a lei em conformidade com a Constituição e expectativa das 
partes, demanda uma atividade interpretativa de densificação da norma geral e abstrata ao plano empírico, que implica na criação e renovação de direito, conforme a teoria circular dos planos, ${ }^{32}$, não se compatibiliza com as ideias positivistas de aplicação imediata da lei, subsunção e declaração do direito pelo juiz, tal qual:

"As questões materiais não são satisfeitas pelo silogismo jurídico, porque a
linguagem do direito é imprecisa, podendo haver conflitos entre as normas,
casos em que a norma a ser aplicada não seja válida por ferir a
Constituição ou, ainda, não existir nenhuma norma suscetível de aplicação no
caso concreto. [...] A regra jurídica serve apenas como uma formulação
provisória, um guia, com funçao meramente indicativa e, portanto,
seguras."

As críticas apresentadas pelo formalismo-valorativo ao positivismo jurídico se fundamentam no argumento de que o positivismo jurídico é insuficiente para servir de amparo como teoria do direito para a realidade jurídica atual, baseada no neoconstitucionalismo e no pós-positivismo, ambas figuras nascidas em decorrência de uma interpretação sistemática do texto constitucional.

Uma das preocupações do formalismo-valorativo consiste em desenvolver uma metodologia jurídico-processual que preserve os valores jurídicos, promovendo uma correção das formas processuais que violem as garantias constitucionais, sem abandonar a segurança jurídica, já que tem como premissa a correção do sistema de direitos, em especial o direito constitucional e os direitos fundamentais.

A filosofia do direito de Habermas ${ }^{34}$ analisada sob o aspecto cooperativo e o formalismo-valorativo propõe a construção de um direito em conformidade com as demandas da sociedade atual, qual seja, democrático, participativo e garantivista, sem, no entanto, representar a perda da segurança jurídica e situações de imprevisão no plano processual, pois ambas são conquistas históricas do direito moderno.

\footnotetext{
${ }^{31}$ HABERMAS, Jürgen. Direito e democracia: entre facticidade e validade. 2. ed. v. 1. Rio de Janeiro: Tempo Brasileiro, 2003. Capítulos IV e V.

32 ZANETI JÚNIOR. Processo Constitucional: o modelo constitucional do processo civil brasileiro. Rio de Janeiro: Lumen Juris, 2007.

${ }^{33}$ CAMBI, Eduardo. Neoconstitucionalismo e Neoprocessualismo. Editora RT, 2009, p. 119.
} 
A busca de soluções jurídicas para os casos concretos deriva de um processo dialético argumentativo, que deve revelar uma decisão reconhecidamente legítima e não uma mera aplicação do texto legal, sem a necessária adequação. A fundamentação desta decisão deverá ser pautada pela coerência de princípios e valores, tais como a ética, a justiça, a boa-fé, a igualdade, a cidadania e a democracia, sobre os quais se assenta o direito.

No projeto do novo Código de Processo Civil, pode-se identificar uma tendência de simplificação do processo civil, alcançada por modificação legislativa que preza por uma postura dos sujeitos do processo que tem por objetivo o respeito aos valores consagrados no ordenamento jurídico e na Constituição Federal, bem como a busca pela concretização da justiça.

Este objetivo é alcançado pela atuação cooperativa entre os sujeitos do processo e na proposta simplificadora do novo código de processo civil, os artigos $5^{\circ}, 7^{\circ}$ e $8^{\circ}, 9^{\circ}$ e 10 demonstram a preocupação com a qualidade e a legitimação das decisões judiciais através da participação efetiva dos envolvidos, inclusive com a normatização do amicus curiae com prerrogativa para intervir em qualquer grau de jurisdição quando, em virtude das peculiaridades do caso, se mostrar adequado e vantajoso e o resultado da causa ultrapassar o interesse inter partes. Diante desta consideração, verifica-se que o projeto de novo Código de Processo Civil abarca uma orientação democrática no processo civil.

A condução do processo cooperativo ocorre baseado na isonomia quando da sua condução, apenas assume caráter assimétrico quando importar na decisão de questões processuais ou materiais. Apenas no momento de decidir é que haverá a prevalência do direito de uma das partes em detrimento da outra, pois a imposição da decisão representa a típica atividade jurisdicional. Apresenta-se paritário no diálogo, porém assimétrico na decisão. ${ }^{35}$

\footnotetext{
${ }^{34}$ HABERMAS, Jürgen. Direito e democracia: entre facticidade e validade. 2. ed. v. 1. Rio de Janeiro: Tempo Brasileiro, 2003. Capítulo V.

${ }^{35}$ ALVARO DE OLIVEIRA, Carlos Alberto. Poderes do Juiz e visão cooperativa do Processo. Disponível em: <http://www.mundojuridico.adv.br>. Acesso em: 20 de outubro de 2011.
} 
O processo cooperativo é fruto do Estado Constitucional, na medida em que a marcha processual será conduzida segundo os valores democráticos, tais como a isonomia da participação das partes, o contraditório e ampla defesa e devido processo legal. O processo deve se desenvolver em um ambiente democrático, igualitário, porém, a proteção jurisdicional deverá ser outorgada assimetricamente, em razão da imperatividade que lhe é inerente.

A investigação da verdade não ocorre somente em decorrência de atos unilaterais, pois provem do esforço combinado das partes, das provas produzidas pelos sujeitos processuais, da argumentação apresentada, evidenciando o caráter da socialidade do saber e da cooperação na busca da verdade, aproximando o julgador da realidade vivida pelas partes.

O processo argumentativo caracteriza-se pela dialética e propõe a colaboração das partes em uma situação controvertida, razão pela qual o contraditório representa o ápice deste diálogo. O Poder Judiciário deverá oportunizar às partes a possibilidade de influenciarem na descoberta da verdade provável, fruto da elaboração doutrinária da ordem estatal.

\section{A BOA-FÉ NO DIREITO COMPARADO}

Ao analisar a boa-fé em outros ordenamentos jurídicos, verifica-se que se trata de uma constante, uma premissa inafastável para que o processo tramite de forma válida e consistente.

É uma tendência da common law a responsabilidade do sujeito pela própria estratégia de atuação adotada. A boa-fé tornou-se, nos ordenamentos contemporâneos, um princípio substancial de notável importância, tal qual:

(...) non puó prescindire dal rilievo dela sua principale caratteristica, ossia l'estrema versatilità a secunda di quelli che risultano essere gli standarts di comportamento di una certa società considerata a sua volta in un determinato momento storico. ${ }^{36}$

A boa-fé no ordenamento inglês é aquela que nasce dos parâmetros de comportamento apropriado, pois em determinados grupos sociais existem certos standarts de comportamento e conduta social, os quais são aprovados pelo corpo social. 
A boa-fé expressa o fundamento moral da atuação, geradora de responsabilidade que deriva da própria conduta legitimada e do respeito e aceitação de determinados comportamentos da parte. A clausula geral da boa-fé é caracterizada por mitigar a vontade singular e constituir um sistema de valores universais.

Trata-se de um estado subjetivo, que operou verdadeira transformação jurídica, através da doutrina e do Poder Judiciário. Este princípio possui grande relevância, havendo doutrinadores que afirmam haver transformado o conceito de sistema e a teoria tradicional das fontes dos direitos subjetivos e dos deveres. ${ }^{37}$

O Código Napoleônico instituiu no seu art. 1.135 o princípio da boa-fé no direito francês, ao dispor que "Les conventions obligent non seulemente à ce qui y est exprimé, mais encore à toutes les suítes qui l'équité, l'usage, ou la loi donnent à l'obligation d'aprés as nature."

Todavia, os juristas da época, da Escola da Exegese, não deram devida atenção ao citado artigo, já que o poder criador da Jurisprudência era limitado. Na época, o ordenamento jurídico apresentava-se fechado, seja em razão das Escolas da época, tais como a Exegese e a Pandectistica, com suas concepções sistemáticas e pautada na separação dos poderes, apregoavam o raciocínio axiomático.

O código civil germânico determinava a interpretação dos negócios jurídicos segundo a boa-fé. Entretanto, não era um dispositivo posto com a finalidade de possibilitar margem criativa ao juiz, mas serviu como fonte aproximativa do direito alemão da common law inglesa. Tal qual apregoado pela doutrina:

\footnotetext{
36 FERRARIS, Eliana. La buona Fede Negli Orientamenti Della Giurisprudenza Inglese, apud O'Connor, Good Faith in English Law, Darmouth, 1990, p. 10. In Rivista del Diritto Commerciale e del Diritto Generale delle Obbligazioni. Roma, 1995, p. 761.

${ }^{37}$ SILVA, Clóvis Veríssimo do Couto e. O Direito Privado Brasileiro na Visão de Clóvis do Couto e Silva; Org. Vera Maria Jacob de Fradera. Porto Alegre: Livraria do Advogado, 1997, p. 34.

${ }^{38}$ SILVA, Clóvis Veríssimo do Couto e. O Direito Privado Brasileiro na Visão de Clóvis do Couto e Silva; Org. Vera Maria Jacob de Fradera. Porto Alegre: Livraria do Advogado, 1997, p. 38

${ }^{39}$ CIMINO,Antônio. La Clausola Generale di Buona Fede Nell'Esperienza Francese, In Rivista del Diritto Commerciale e del Diritto Generale delle Obbligazioni. Roma, 1996, p. 790.
} 
Começava a reconhecer-se no princípio da boa-fé uma fonte autônoma de direitos e obrigações; transforma-se a relação obrigacional manifestando-se no vinculo dialético e polemico, estabelecido entre devedor e credor, elementos cooperativos necessários ao correto adimplemento. ${ }^{38}$

O princípio da boa-fé endereça-se sobretudo ao juiz e o insta a formar instituições para responder aos novos fatos, exercendo controle corretivo do Direito estrito, já que a boa-fé possui um valor autônomo, não vinculado à mera manifestação de vontade, criando carga obrigacional objetiva.

No ordenamento inglês, o parâmetro da boa-fé foi posto em direta relação com o dever de lealdade, como a construção de uma concessão moral indispensável em um contexto econômico e jurídico como o que se tem atualmente, exigindo da parte uma atuação positiva na concretização da obrigação assumida. ${ }^{39}$

No processo inglês, há um procedimento especial chamado Discovery em que o advogado da parte é obrigado a entregar todos os documentos que poderiam ser necessários para esclarecer a situação. Trata-se do dever de colaboração com processo, na medida em que disponibiliza todos os documentos elucidativos da causa. ${ }^{40}$

Assim, verifica-se que nos ordenamentos jurídicos europeus, existe igualmente a preocupação com a atuação cooperativa das partes, como decorrência do princípio da boa-fé processual, necessário para se alcançar decisões justas nos casos concretos, os quais deverão ser analisados segundo as provas produzidas nos autos, de modo a refletir a verdade vivenciada pelas partes.

\section{CONSIDERAÇÕES FINAIS}

A realização do modelo de Estado Democrático de Direito pressupõe a atuação legítima do Poder Judiciário de forma autônoma e independente com o fim de exercer a adequada tutela dos diretos e garantias fundamentais. O exercício equânime da jurisdição deve priorizar os direitos e garantias fundamentais, como forma de legitimação do exercício da função judicante à luz da denominada jurisprudência de valores constitucionais.

\footnotetext{
${ }^{40}$ ZITSCHER, Harriet Christiane. Introdução ao Direito Civil Alemão e Inglês. Belo Horizonte: Del Rey, 1999, p.66.
} 
O direito de ação ou de socorro ao Poder Judiciário para que este exerça sua função pacificadora, deve ser pensado como direito à efetiva tutela jurisdicional, não bastando uma sentença meritória, mas buscando uma solução que seja passível de ser implementada, concretizada segundo clama a realidade social, possibilitando às partes uma participação democrática no plano processual.

Se o direito objeto do litígio constituir um direito fundamental, a atuação jurisdicional deverá sempre ser pautada pela celeridade, a fim de garantir eficácia à tutela jurisdicional, com vistas à ampla, irrestrita e integral interpretação das normas do processo como forma de viabilizar a concretização imediata desses direitos, a fim de lhes garantir a proteção ou exercício pleno pelo cidadão, reforçando a atuação democrática dos sujeitos no plano das relações jurídico-processuais.

A necessária paridade na condução do processo encontra-se também na necessidade de possibilitar a manifestação da parte antes do juiz decidir assimetricamente, ou seja, oportunizar às partes um debate prévio antes de extinguir o processo sem julgamento do mérito, inclusive naquelas situações em que o juiz deve agir de ofício, e também no que se refere ao conhecimento das matérias de ordem pública.

A decisão jurisdicional somente é eficaz e se legitima, após um amplo debate entre as partes, ocorrido em condições de paridade, de igualdade e de acesso ao processo. Trata-se da participação democrática da parte no plano processual, no sentido de litigar em igualdade de condições a fim de obter um resultado favorável por meio do acesso paritário ao processo, vencendo aquele que apresentar o melhor argumento.

A visão cooperativa do processo privilegia o contraditório entre os sujeitos do processo mediante o imperativo do direito de influência e dever de debates, bem como a decisão deverá ser apresentada como um resultado dos debates realizados no âmbito processual, caracterizada pela simetria entre os sujeitos do processo, a qual é rompida apenas no momento decisional em que o juiz, em atividade cognitiva concede o direito a um das partes.

Esta cooperação no plano do processo implica em diversos desdobramentos, tais como a necessidade de um ativismo judicial voltado para a garantia da paridade nas condições de atuação dos sujeitos no processo, mantendo-se, assim, um contraditório real; a 
fundamentação das decisões e argumentos, afastando-se a aplicação do silogismo jurídico, a fim de demonstrar suficientemente a adequação da lei à Constituição e garantir aplicabilidade dos princípios em geral, cláusulas abertas e conceitos jurídicos indeterminados - resultando na natureza criativa da decisão judicial, a fim de melhor se adaptar à realidade das partes; possibilitar a participação no processo de outros sujeitos, que não os tradicionalmente admitidos, com legitimidade para defender os direitos que extrapolam os interesses das partes.

O magistrado, diante dos princípios preconizados pelo Estado Democrático Constitucional, deve adequar a lei ao caso concreto, atuando como verdadeiro intérprete sem abandonar a visão da necessária cooperação no plano processual, situação que demanda uma atividade interpretativa da norma geral e abstrata ao plano empírico, ocasionando a criação e renovação de direito.

A relação jurídica processual democrática exige deliberações comuns, pressupõe a existência de espaços públicos abertos que permitam às partes a discussão de questões jurídicas relevantes. A promoção do diálogo não deve se fazer através do acirramento de disputas, mas no incentivo na obtenção de argumentos racionais necessários à efetivação dos resultados que atendam aos interesses individuais, aos preceitos constitucionais e aos objetivos da ordem estatal constitucional.

\section{REFERÊNCIAS}

ALEXY, Robert. La Construcción de Los Derechos Fundamentales. Buenos Aires: Ad- hoc, 2010.

ALVARO DE OLIVEIRA, Carlos Alberto. Do formalismo no processo civil: proposta de um formalismo-valorativo. 3. ed. São Paulo: Saraiva, 2009.

ALVARO DE OlIVEIRA, Carlos Alberto. Poderes do Juiz e visão cooperativa do Processo. Disponível em: 〈http://www.mundojuridico.adv.br>. Acesso em: 20 de outubro de 2011. 
ARRUDA. Samuel Miranda. O Direito Fundamental à Razoável Duração do Processo. Brasília: Editora Brasília Jurídica. 2006.

BARBOSA MOREIRA, José Carlos. Os Poderes do juiz na direção e na instrução do processo. Temas de direito processual civil $-4^{\mathrm{a}}$ série. São Paulo: Saraiva, 1989.

BARBOSA MOREIRA, José Carlos. O neoprivatismo no processo civil. Leituras complementares de processo civil. $7^{\text {a }}$ Ed.. Salvador: JusPodium, 2009.

BOBBIO, Norberto. O Futuro da Democracia: Uma defesa das regras do jogo. Rio de Janeiro: Paz e Terra. 1997.

BRASIL JÚNIOR, Samuel Meira. Justiça, direito e processo: a argumentação e o direito processual de resultados justos. São Paulo: Atlas, 2007.

BUENO, Cássio Scarpinella. Curso Sistematizado de Direito Processual Civil, vol. 1. São Paulo: Saraiva, 2011.

CAMBI, Eduardo. Neoconstitucionalismo e Neoprocessualismo. Editora RT, 2009.

CAPPELlETTI, M.; GARTH, B. apud SILVA, Carlos Augusto. O processo civil como estratégia de poder: reflexo da judicialização da política no Brasil. Rio de Janeiro: Renovar, 2004. p. 32-33.

CAPPELLETTI, Mauro. Acesso à Justiça. Rio de Janeiro: Ed. Renovar, 2001.

CIMINO, Antônio. La Clausola Generale di Buona Fede Nell'Esperienza Francese, In Rivista del Diritto Commerciale e del Diritto Generale delle Obbligazioni. Roma, 1996.

CORREIA. Marcos Orione Gonçalves. Direito Processual Constitucional. São Paulo: Saraiva, 2007.

COUTURE. Eduardo. Fundamentos del Derecho Procesual Civil. Buenos Aires: Ediciones Depalma. 1972.

DIDIER Júnior, Fredie. Os Três Modelos de Direito Processual: Inquisitivo, Dispositivo e Cooperativo. In Revista de Processo, Ano 36, vol. 198, Agosto de 2011. Coordenação Teresa Arruda Alvim Wambier. São Paulo: Editora do Tribunais, 2011. 
DINAMARCO, Cândido Rangel. A instrumentalidade do processo. 13. ed. São Paulo: Malheiros, 2008.

FAZZALARI, Elio. L'esperienza del processo nella cultura contemporânea. Rivista di diritto processuale, 1965.

FILHO. Vicente Greco. Direito Processual Civil Brasileiro. Vol. 1. São Paulo: Saraiva, 2008.

HABERMAS, Jürgen. Direito e democracia: entre facticidade e validade. Vol. I, 2. ed. Rio de Janeiro: Tempo Brasileiro, 2003.

HARBERMAS, Jürgen. Direito e Democracia: entre facticidade e validade. Vol II. Rio de Janeiro: Tempo Brasileiro, 1997.

MARINONI, Luiz Guilherme; ARENHART, Sérgio Cruz. Curso de Processo Civil. São Paulo: Ed. RT, 2008.

MARINONI, Luiz Guilherme; MITIDIERO, Daniel. O Projeto do CPC: Críticas e Propostas. São Paulo: Ed. RT, 2010.

MARINONI, Luiz Guilherme. Derecho Fundamental a la tutela jurisdicional efectiva. Editora Palestra, São Paulo: 2007.

MARQUES. José Frederico. Instituições de direito processual civil, vol. II. Rio de Janeiro: Forense, pg. 120 a 123.

MEDINA. Paulo Roberto de Gouvêa. Direito Processual Constitucional. Rio de Janeiro: Forense, 2010.

MIRANDA, Pontes de. CAVAlCANTI. Francisco. Prólogo. Comentários ao Código de Processo Civil. $2^{\text {a }}$. Ed. Rio de Janeiro: Forense, 1958.

MITIDIERO. Daniel. Colaboração no processo civil. Pressupostos sociais, lógicos e éticos. São Paulo: RT, 2009. 
NUNES. Dierle José Coelho. Processo jurisdicional democrático. Curitiba: Juruá, 2008. OLIVEIRA, Carlos Alberto Álvaro de. Garantia do contraditório. Garantias constitucionais do processo civil. São Paulo: Ed. RT, 1999.

PASSOS. Calmon. O Devido Processo Legal e o Duplo Grau de Jurisdição. São Paulo: Saraiva, 1981.

PICARDI, Nicola. Jurisdição e processo. Rio de janeiro: Forense, 2008.

PONTE NETO, José Júlio. O Poder Judiciário e a concretização da Democracia Participativa. Revista Sequiência, n. 56, p. 205-224, jun 2008.

SILVA, Clóvis Veríssimo do Couto e. O Direito Privado Brasileiro na Visão de Clóvis do Couto e Silva; Org. Vera Maria Jacob de Fradera. Porto Alegre: Livraria do Advogado, 1997, p. 34.

SILVA. José Afonso. Comentário Contextual à Constituição. São Paulo: Malheiros. 2005. SILVA, José Afonso. Curso de Direito Constitucional Positivo, São Paulo: Ed. Malheiros. 2009.

SILVA. Ovídio Batista. Processo e Ideologia: O Paradigma Racionalista. Rio de Janeiro: 2006.

ZANETI JÚNIOR. Processo Constitucional: o modelo constitucional do processo civil brasileiro. Rio de Janeiro: Lumen Juris, 2007.

ZITSCHER, Harriet Christiane. Introdução ao Direito Civil Alemão e Inglês. Belo Horizonte: Del Rey, 1999. 